\title{
Conservative approach for anterior crown-root fractured teeth: forced eruption
}

\author{
Ji-Eun Kim ${ }^{1 a}$, Sung-Hyeon Choi ${ }^{2 a}$, Hoon-Sang Chang, Yun-Chan Hwang', In-Nam Hwang', Won-Mann Oh* \\ 'Department of Conservative Dentistry, School of Dentistry, Chonnam National University, Gwangju, Republic of Korea \\ 2Department of Conservative Dentistry, Chonnam National University Dental Hospital, Gwangju, Republic of Korea
}

In the case of crown-root fracture due to traumatic injury in anterior tooth and the fracture margin is located subgingivally, forced eruption has been proposed for the reconstruction of deficient bone and soft tissue. Forced eruption is one of the easiest orthodontic approaches that can have an acceptable outcome and prognosis, and has a low incidence of relapse. However, using heavy forces or very fast movements can also cause tissue damage or ankylosis. The following case reports present forced eruption as treatment option of crown fracture in maxillary anterior teeth. (J Dent Rehabil Appl Sci 2020;36(1):48-54)

Key words: aesthetic; anterior tooth; crown-root fracture; forced eruption

서론

치관-치근 파절은 법랑질, 상아질, 백악질에 파급된 파 절이며 치수노출을 수반하는 것과 수반하지 않는 것이 있다. 치근의 파절선이 치관부에 근접한 경우 느슨한 치 아 파절편을 제거한 후 긴 접합상피가 형성되도록 치은 을 노출된 상아질에 맞게 적합시키거나, 외과적으로 파 절 부위를 노출시키거나, 교정적 또는 외과적으로 치아 를 정출시키는 방법을 고려해 볼 수 있다. ${ }^{1}$

파절선의 위치에 따라 수복 방법이 다양하며 특히 치은 연하로 파절되었을 때 수복물은 생물학적 폭경의 재확립 을 필요로 하게 된다. 이상적인 치은의 부착구조인 생물 학적 폭경이 보철물 변연 등으로부터 침해 받았을 경우 염증과 치은출혈이 발생할 수 있으며 부착소실과 치주낭 의 형성을 초래할 수 있으므로 치주 및 보철 시술 시 각별

*Correspondence to: Won-Mann Oh

Professor, Department of Conservative Dentistry, School of Dentistry, Chonnam National University, 77 Youngbong-ro, Buk-gu, Gwangju, 61186, Republic of Korea Tel: +82-62-530-5572, Fax: +82-62-530-5629, E-mail: wmoh@chonnam.ac.kr Received: February 19, 2020/Last Revision: February 26, 2020/Accepted: February 26, 2020

a Ji-Eun Kim and Sung-Hyeon Choi contributed equally to this work as first authors.
히 유의해야 한다. ${ }^{2}$ 생물학적 폭경을 유지하기 위한 방법 으로 치은절제술, 치조골성형술, 교정적 치아정출술, 외 과적 정출술 등이 있다.

정상적인 치아조직을 외과적으로 노출시키게 되면 비 심미적인 결과를 얻을 수 있다. 치은과 치조골 수술은 해 당치아뿐만 아니라 인접치의 치은과 골 풍융부 형태에도 영향을 미치며 치근의 민감성도 가져올 수 있다. ${ }^{3}$

교정적 정출술을 시행하게 되면 파절선을 치은 상방으 로 노출시키고 생물학적 폭경을 재확립할 수 있다. 또한 심미성을 극대화 할 수 있으며 경우에 따라 치수생활력 도 유지할 수 있다는 장점이 있다.

본 증례는 두 환자에서 외상으로 인한 상악 전치의 복 합 치관-치근 파절에 대해 교정적 정출술을 이용하여 보 존적이고 심미적인 치료 결과를 얻은 증례 보고와 술식 시 고려해야 할 사항에 대해 보고하고자 한다. 


\section{증례보고}

\section{증례 1}

28세 여성으로 걷다가 넘어져서 발생한 상악 우측 중 절치(\#11)와 우측 측절치(\#12) 치관파절을 주소로 내원 하였다. 파절선의 순측은 치은상방에 위치하고, 근심면 과 구개측은 치은 하방 $2 \mathrm{~mm}$ 에 위치하였다. 상악 좌측 중철치(\#21)와 우측 중절치(\#11)에는 절단연 파절이 있 었다(Fig. 1).

치료계획은 \#12의 근심면과 구개측 파절선이 치은하 방으로 $2 \mathrm{~mm}$ 정도에 위치하여 교정적 치아 정출술을 시 행하기로 하였다. 근관치료를 먼저 시행하였고 잔존치 관의 높이가 상대적으로 길어 hook를 이용한 교정적 정 출술을 하기에 적절치 않다고 판단하여 직경 $2 \mathrm{~mm}$ 의 Silver Mini Tube Appliance (MTA, HUBIT, Anyang, Korea)를 이용하였다. \#11, 13 치아에는 NiTi wire가 수 동적으로(passive) 삽입될 수 있도록 \#11, 13 순면 중앙 부위에 MTA를 접착하였고, \#12 순면에는 MTA를 \#11, 13 순면에 붙인 위치보다 치근측으로 $1.5 \mathrm{~mm}$ 이동시켜 접착함으로써 불필요한 치아 이동 없이 \#12에만 순수 정 출력을 주도록 하였다. 최대한 약하고 지속적인 힘을 주
기 위해 012 NiTi wire (HUBIT, Anyang, Korea)를 삽 입했고, 인접치 이동을 막기 위해 인접치들의 구개측에 0195 twistflex wire (Dentaflex, DENTAURUM, Ispringen, Germany)로 palatal retainer를 부착하였다(Fig. 2).

별도의 tube위치 조정 없이 4주 간격으로 2회, 총 2개월 동안 교정력을 가해 $3 \mathrm{~mm}$ 정출시킴으로써 구개측의 파 절선이 치은상방으로 노출되면서 ferrule을 위한 치질을 확보하였고, 방사선 사진으로도 \#12 치아가 절단연 쪽 으로 이동되었음을 관찰 할 수 있었다. 교정적 정출술 진 행 후 상방으로 증식한 치은을 절제하기 위해 치은절제 술도 함께 시행하였다.

\#12 치아에 포스트(Luxapost, DMG, Hamburg, Germany) 식립하여 코어(LuxaCoreZ, DMG) 수복한 후 지르코니아 전장관으로 최종 수복하였다(Fig. 3).

또한 탈구 후 정복 시행한 \#11 치아에 대해 2주 후 임 상검사와 방사선검사결과 타진반응에는 양성, 냉검사와 전기치수검사에는 음성반응을 보여서 치수괴사로 진단 후 근관치료를 시행하였다. 절단면 파절된 \#11, 21 치아 는 복합레진으로 수복하였다. 6개월 후 정기검진 시 환자 와 술자 모두 심미적, 기능적인 면에서 만족하였으며 좋 은 예후를 보이고 있다(Fig. 4).
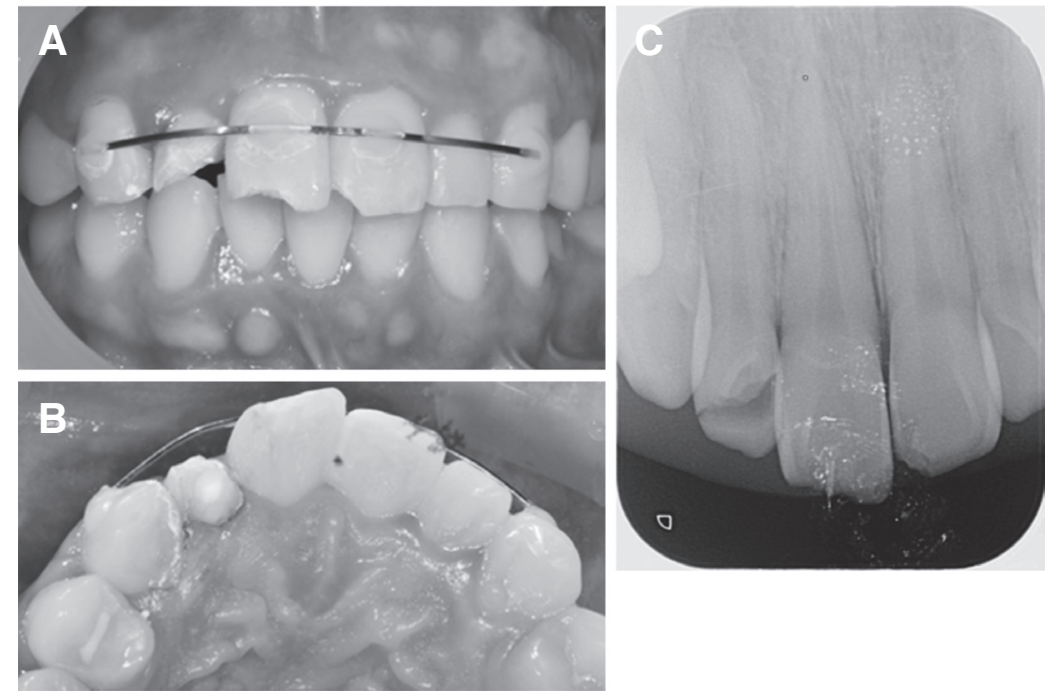

Fig. 1. (A) Pretreatment frontal view of the fractured maxillary right lateral incisor, (B) Pretreatment palatal view of the fractured maxillary right lateral incisor, (C) Radiograph of maxillary right lateral incisor before treatment.

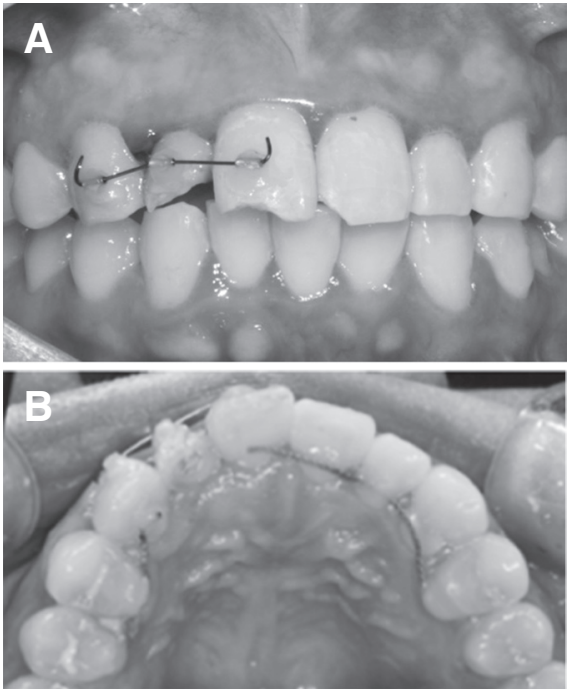

Fig. 2. (A) Frontal view during forced eruption, (B) Palatal view during forced eruption. 

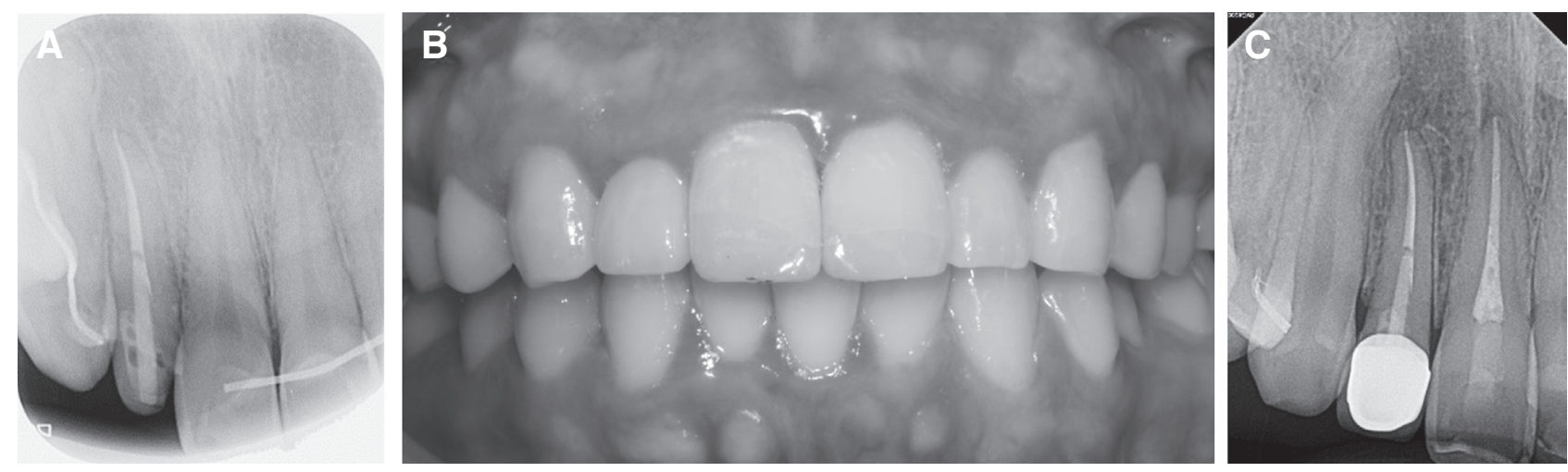

Fig. 3. (A) Radiograph of maxillary right lateral incisor after post and core restoration, (B) Post-treatment frontal view of maxillary right lateral incisor, (C) Radiograph of maxillary right lateral incisor after treatment.
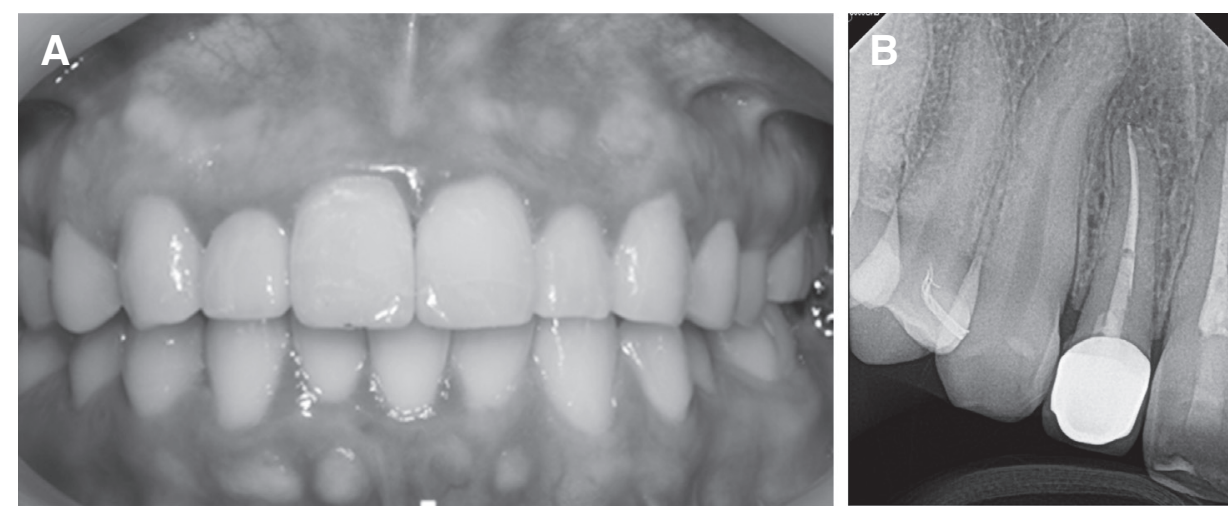

Fig. 4. (A) Post-treatment frontal view of maxillary right lateral incisor after 6 months, (B) Radiograph of maxillary right lateral incisor after 6 months.

\section{증례 2}

22세 남성으로 상악 우측 중절치(\#11) 치관파절을 주 소로 내원하였다. 임상검사와 방사선 검사 결과 \#11 치 아가 타진에 반응 없고 동요도 없었으나, 근심측 파절선 이 치은하방 $2 \mathrm{~mm}$ 에 위치하였고, \#11 순측에 치은부종 과 발적이 있었다(Fig. 5).

7년 전에 근관치료를 받았던 기왕력이 있었던 \#11 치 아를 재근관치료 후 교정적정출술을 시행하기로 하였다. 재근관치료 진행 후 \#13-23 순면에 $0.9 \mathrm{~mm}$ round SS wire를 유동성 복합레진을 사용하여 부착하였다. Power chain (CLEAR GENERATION II, ORMCO, Scafati, Italy)과 elastic thread 0.25"(Clear Slip-Not Elastic Power Thread, G\&H Wire Company, Indiana, USA)를 이용
하여 80 - $100 \mathrm{gm}$ 의 정출력을 부여하였다(Fig. 6). 생활치 의 정출을 위해서 20 - $30 \mathrm{gm}$ 의 힘을 넘지 않아야 하며 7 - 8주 사이에 완료되어야 하지만, ${ }^{4}$ 본 증례의 경우 실활치 이었기 때문에 생활치에서보다 더 강한 힘을 적용하였고 dial gauge를 이용하여 측정하였다.

6주 후 \#11 순측 부착치은이 상악 좌측 중절치(\#21) 에 비해 치관방향으로 $1 \mathrm{~mm}$ 이동하여 심미적 이유로 치 은절제술 권유드렸으나 환자분이 수술적 방법을 원하지 않아 시행하지 않았다. 3 주 간격으로 6 주 동안 교정력을 가해 총 $3 \mathrm{~mm}$ 정출되었다. 교정적 정출술 진행 후 \#11 치아에 포스트(Luxapost, DMG) 식립 및 코어(LuxaCoreZ, DMG) 수복한 후 최종적으로 지르코니아 전장 관으로 수복하였다(Fig. 7). 

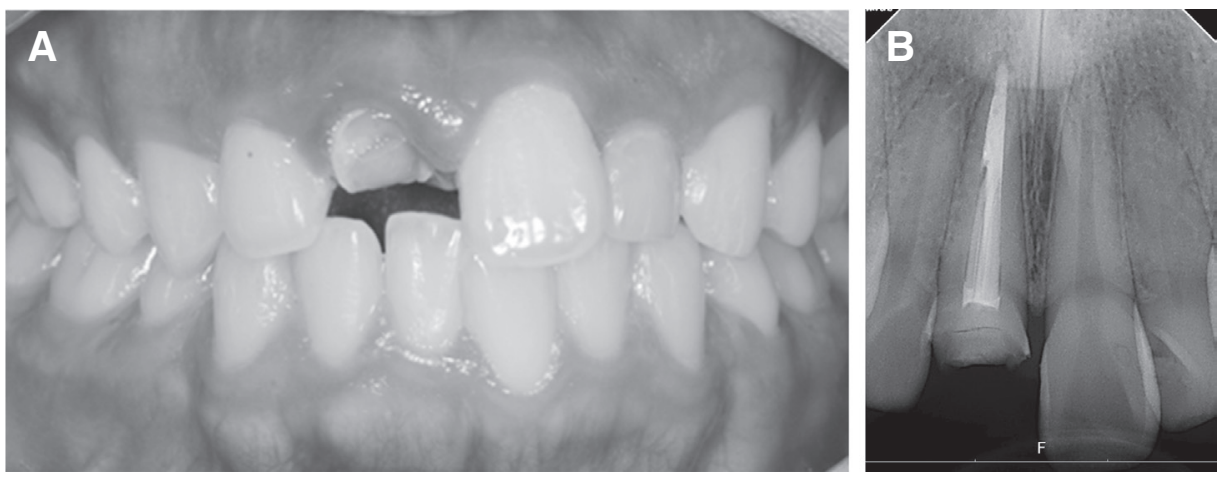

Fig. 5. (A) Pretreatment frontal view of the fractured maxillary right incisor, (B) Radiograph of maxillary right incisor before treatment.

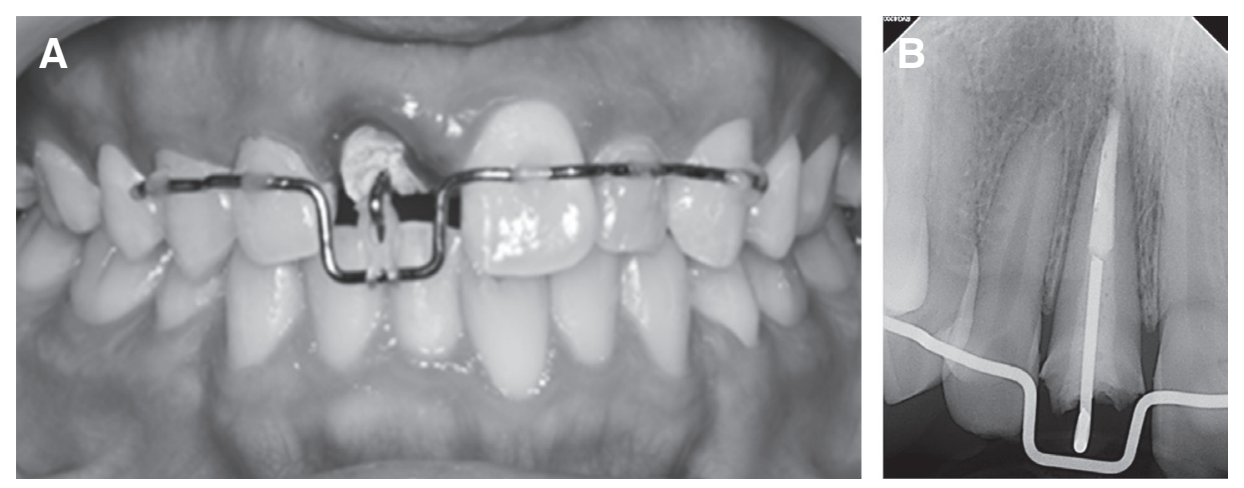

Fig. 6. (A) Frontal view during forced eruption, (B) Radiograph of maxillary right incisor during forced eruption.
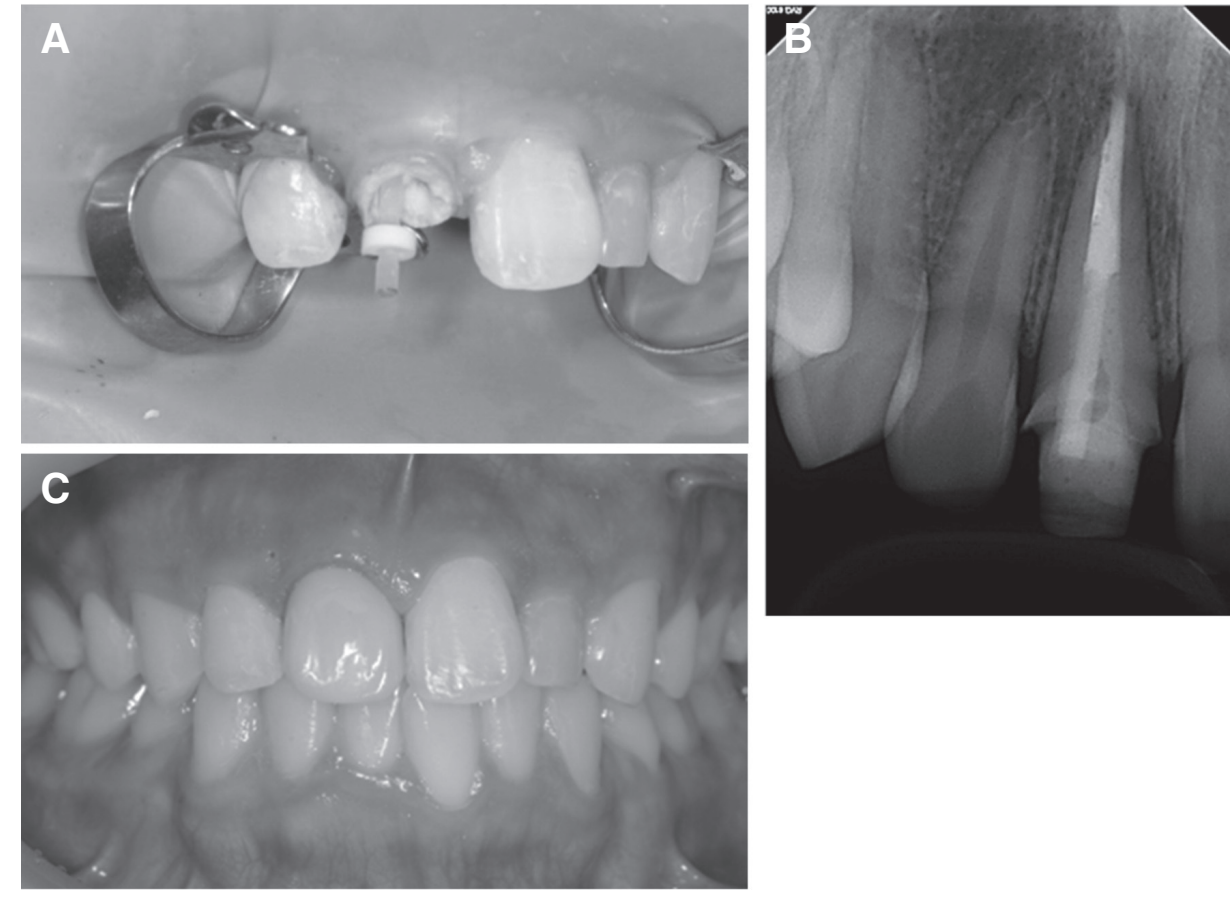

Fig. 7. (A) Frontal view during post insertion, (B) Radiograph of maxillary right incisor after post and core restoration, (C) Post-treatment frontal view of maxillary right incisor. 


\section{고찰}

1973년 Heithersay 등 ${ }^{5}$ 에 의해 제안된 교정적 치아 정 출술은 약하고 지속적인 교정력을 적용하여 치아를 치관 방향으로 이동시키는 술식을 말한다. Reitan 등 ${ }^{6}$ 에 따르 면 정출하는 치아의 움직임으로 치은과 치주인대가 신장 하게 되고 연조직과 골조직이 치관측으로 이동하게 된 다.

교정적 정출술로 생물학적 폭경을 유지하면서 건전한 치질을 노출시켜 심미적으로도 수복물 변연을 적절하게 위치시킬 수 있다. ${ }^{7}$ 전장관으로 수복하기 위해 치아를 삭 제할 때 수복물의 안정적이고 좋은 예후를 위해 변연은 건전한 치아 구조 내에 위치해야 한다. 이 때 1.25 - 2.5 $\mathrm{mm}$ 의 ferrule이 필요하다. 생물학적 폭경이란 치조능 상 방으로 치근에 부착된 접합상피와 결합조직부착을 합한 크기(약 $2 \mathrm{~mm}$ )로 보철물 변연이 치관부 부착을 침범하 지 않기 위해 치조능으로부터 최소 3.5-4 mm는 떨어져 있어야 한다. ${ }^{8}$ 특히 치아의 변연이 치은하방일 경우 생물 학적 폭경을 확보하기 위하여 교정적 정출술이 널리 시행 되어 왔다. ${ }^{9}$

치관과 치근비율은 치아의 예후를 예측하는데 도움이 된다. 이상적인 임상적 치관과 치근의 비율은 $1: 2$ 가 되어 야 하며 적어도 $1: 1$ 의 비율은 유지해야 한다. Ayus 등 ${ }^{10}$ 에 의하면 교정적 정출술을 시행하게 되면 외과적으로 처치 한 경우보다 상대적으로 개선된 치관 대 치근 비율을 얻 을 수 있다고 하였다. 증례 2의 경우 방사선 사진으로부 터 측정된 치근의 길이는 $14 \mathrm{~mm}$ 였다. $4 \mathrm{~mm}$ 정출 후에도 여전히 1:1보다 유리한 치관 대 치근 비율을 유지하고 있 다.

교정적 정출술을 시행할 때 부착치은의 너비는 증가하 게 되고 치은변연이 치관측으로 이동할 때 치은점막경계 부는 그대로 유지된다. 교정적 정출술 후 치주수술을 함 으로써 악궁의 인접치아와 조화를 이루어 심미적인 치관 형태로 복원할 수 있다. ${ }^{11}$ 본 증례 1 에서도 상방으로 증식 한 치은을 절제하여 보다 더 심미적으로 수복할 수 있었 다.

교정적 정출술은 일반적으로 wire와 hook을 부착하 여 진행하는데 구강위생관리의 어려움, 비심미적이라는 문제점이 있다. 따라서 본 증례 1 에서는 전치부 부분교 정에 사용되는 MTA를 이용하여 진행하였다. MTA는 3 $\mathrm{mm}$ 정도 크기의 mini tube를 사용하기 때문에 이물감이 나 통증이 거의 없고 심미적이다. 또한 $012 \mathrm{NiTi}$ wire를
사용하기 때문에 마찰저항이 적고 빠른 이동이 가능하다 는 장점이 있다. 그리고 기존 브라켓에 비해 탈락률이 낮 으며 이동이 빠르다. ${ }^{12}$ 본 증례 1 에서는 상대적으로 치관 의 길이가 길어 hook을 삽입하여 치관을 정출하기에 적 합하지 않다고 판단하여 잔존하는 치관의 협면에 MTA 를 부착하여 교정적 정출술을 시행하였다. MTA를 부착 하였을 때 정출력을 가하기 위해 이용하였던 기존의 wire 보다 더 심미적이었으며 더 빠른 기간 안에 치아를 정출 시킬 수 있었다.

일반적으로 상악 전방부 치아의 치근이 치근첨보다 상 방으로 갈수록 근원심 폭경의 경사도가 감소하게 된다. 경사가 큰 치근의 경우 치근이 정출됨에 따라 치경부직경 은 감소하고 전장관수복물은 상대적으로 넓어져 치간공 극은 커지게 된다. ${ }^{13}$ 본 증례들에서는 수복물 제작 시 접 촉점으로부터 순측방향으로는 과풍융되지 않는 정도에 서 black triangle이 최대한 생기지 않도록 심미적으로 디 자인하였고, 접촉점으로부터 구개측방향으로는 세정이 잘 될 수 있도록 출현윤곽에 있어서 기능적인 부분을 고 려하여 수복물을 제작하였다.

교정적 정출술의 최종 결과는 보다 더 심미적이고 생리 적인 결과를 가져오는데 기여한다. 치은변연의 위치 또한 원래의 수준에 가까워지고 치관과 치근 비율이 상대적으 로 개선될 수 있다. 이로 인해 수술적 처치에 의해 발생할 수 있는 비심미적인 부분을 해소 할 수 있다.

연조직과 경조직 사이 및 인접한 치아의 치주사이에 조 화가 존재해야 한다. 종종 인접치아에 대한 후속치료의 필요성을 최소화 하기 위해 교정적 정출술과 치관연장술 이 조합되어 치관과 치근 비율을 개선하고 보다 더 심미 적인 결과를 얻을 수 있다.

\section{결론}

본 증례에서는 외상으로 인한 상악 전치의 복합 치관치근 파절에 대해 교정적 정출술을 이용하여 비교적 충 분한 임상치관 길이를 확보할 수 있었다. 교정적 정출술 을 시행했을 때 외과적 처치에 비해 치관 대 치근 비율을 개선시킬 수 있었고 심미적인 결과를 얻을 수 있었다.

\section{ORCID}

Ji-Eun Kim https://orcid.org/0000-0003-0634-3082

Sung-Hyeon Choi https://orcid.org/0000-0002-4324-6567 
Hoon-Sang Chang https://orcid.org/0000-0002-3019-1528

Yun-Chan Hwang https://orcid.org/0000-0002-7891-9565

In-Nam Hwang https://orcid.org/0000-0002-5388-1919

Won-Mann Oh https://orcid.org/0000-0001-6480-6191

\section{References}

1. Poi WR, Cardoso Lde C, de Castro JC, Cintra LT, Gulinelli JL, de Lazari JA. Multidisciplinary treatment approach for crown fracture and crown-root fracture - a case report. Dent Traumatol 2007;23: $51-5$.

2. Stevens BH, Levine RA. Forced eruption: a multidisciplinary approach for form, function, and biologic predictability. Compend Contin Educ Dent 1998;19:994-8, 1000, 1002-4 passim.

3. Ingber JS. Forced eruption: part II. A method of treating nonrestorable teeth-periodontal and restorative considerations. J Periodontol 1976;47:203-16.

4. Geiger AM, Bronsky MJ. Orthodontic management of ankylosed permanent posterior teeth: a clinical report of three cases. Am J Orthod Dentofacial Orthop 1994;106:543-8.

5. Ziskind D, Schmidt A, Hirschfeld Z. Forced eruption technique: rationale and clinical report. J Prosthet Dent 1998;79:246-8.

6. Reitan K. Clinical and histologic observations on tooth movement during and after orthodontic treatment. Am J Orthod 1967;53:721-45.

7. Emerich-Poplatek K, Sawicki L, Bodal M, Adamowicz-Klepalska B. Forced eruption after crown/root fracture with a simple and aesthetic method using the fractured crown. Dent Traumatol 2005;21:1659 .

8. Khuller N, Sharma N. Biologic width: Evaluation and correction of its violation. J Oral Health Comm Dent. 2009;3:20-5.

9. Stern N, Becker A. Forced eruption: biological and clinical considerations. J Oral Rehabil 1980;7:395402.

10. Potashnick S, Rosenberg ES. Forced eruption: principles in periodontics and restorative dentistry. J Prosthet Dent 1982;48:141-8.

11. Kwon EY, Lee JY, Choi J. Effect of slow forced eruption on the vertical levels of the interproximal bone and papilla and the width of the alveolar ridge. Korean J Orthod 2016;46:379-85.

12. Kim SY, Lee SH, Lee NY, Jih MK. Forced eruption with customized resin tube appliance. Oral Biol Res 2018;42:45-52.

13. Singh AR, Verma R. Crown lengthening vs forced eruption. Orthodont J Nepal 2011;1:52-5. 


\title{
상악 전치부 치관-치근 파절 증례에서의 보존적 접근법: 교정적 정출술
}

\author{
김지은 ${ }^{1 \mathrm{a}}$ 대학원생, 최성현 ${ }^{2 \mathrm{a}}$ 전임의, 장훈상 ${ }^{1}$ 교수, 황윤찬 ${ }^{1}$ 교수, 황인남 ${ }^{1}$ 교수, 오원만 ${ }^{*}$ 교수
}

${ }^{1}$ 전남대학교 치과대학 보존학교실

${ }^{2}$ 전남대학교 치과병원 치과보존과

상악 전치부 외상으로 인한 치관-치근 파절의 경우 파절선이 치은연하에 위치할 때 결손된 골조직과 연조직을 재생성하 기 위해 교정적 정출술이 제안되었다. 교정적 정출술은 심미적인 결과와 좋은 예후를 나타내는 쉬운 교정 접근법 중 하나 이다. 그러나 강한 힘을 사용하거나 매우 빠른 교정력을 가하게 되면 조직손상이나 유착이 발생할 수 있다. 다음 증례는 두 환자에서 외상으로 인한 상악전치의 치관-치근 파절에 대해 교정적 정출술을 이용한 임상치료과정을 서술하였다.

(구강회복응용과학지 2020;36 (1):48-54)

주요어: 교정적 정출술; 심미; 전치부; 치관-치근 파절

*교신저자: 오원만

(61186)광주광역시 북구 용봉로77 전남대학교 치과대학 보존학교실

Tel: 062-530-5572 | Fax: 062-530-5629 | E-mail: wmoh@chonnam.ac. kr

접수일: 2020년 2월 19일 | 수정일: 2020년 2월 26일 | 채택일: 2020년 2월 26일

${ }^{\mathrm{a}}$ 이 연구에 공동 제 1 저자로서 작업함. 